\title{
La crisis del liberalismo y los orígenes del "autoritarismo moderno" y del Estado Novo en Portugal
}

\author{
FERNANDO ROSAS *
}

\section{INTRODUCCIÓN}

Es punto comúnmente aceptado por la historiografía portuguesa del período contemporáneo que la crisis del sistema monárquico constitucional, finalmente implantado en 1834 tras las convulsiones posteriores al pronunciamiento liberal de 1820 , se abre en el inicio de la última década del siglo $x I X$.

La crisis política, económica y financiera de 1890-1891 — marcada por la bancarrota financiera del Estado portugués, en simultaneidad con la tempestad política originada por el cultimátum» británico del 11 de enero de 1890 - ${ }^{1}$ señala en realidad el comienzo del fin del régimen monárquico, derribado por la revolución republicana del 5 de octubre de 1910. Pero, como han subrayado recientes trabajos ${ }^{2}$, este acontecimiento parece significar más que el simple comienzo del proceso de superación de cierta «forma» de Estado, el arranque de la larga crisis del sistema liberal portugués, que vendrá a desembocar en la dictadura militar de 1926 y, después, en el Estado Novo.

* Traducción Hipólito de la Torre.

El 11 de enero de 1890 el Gobierno británico intimó al Gobierno portugués a que abandonara en el plazo de pocas horas, so pena de represalias políticas y militares, parte de los territorios que explotaba entre las colonias africanas de Angola y Mozambique, con el fin de hacer posible la expansión británica hacia el norte a partir de África del Sur. El "uitimatum" fue aceptado ese mismo día por la Corona portuguesa, lo que originó grandes manifestaciones patrióticas de protesta contra Gran Bretaña y contra la monarquía.

${ }^{2}$ Cf. Villaverde Cabral, Manuel, Portugal na Alvoroada do século xx. Lisboa, Ed. Regra do Jogo, 1979. 
El objetivo de la presente comunicación es el análisis sumario de algunos factores de la crisis del sistema liberal monárquico portugués a finales del siglo pasado, así como de las grandes líneas de la dinámica contradictoria de las alternativas que históricamente pretenden su sucesión. En este contexto, se tratará de captar de forma resumida la aparición y las peculiaridades del fenómeno del "autoritarismo moderno" y de su trayectoria hasta los orígenes del Estado Novo.

\section{LA CRISIS DEL SISTEMA LIBERAL MONÁRQUICO}

La ola de indignación nacionalista antibritánica que sacude al país (especialmente a sus centros urbanos), tras la aceptación por el Rey don Carlos y por las altas instituciones políticas de la monarquía del diktat de Londres en enero de 1890, no se limita a originar una compleja crisis gubernativa, sino que viene a poner de manifiesto el impasse del sistema político-institucional de la monarquía liberal.

En la violencia de los ataques desencadenados por entonces contra el Rey, contra la dinastía de Braganza, contra la corona y sus apaniaguados consejeros en la gobernación del país, en cuyo contexto la ofensiva del republicanismo asocia la monarquía al propio origen de la «decadencia nacional» que la patria estaría atravesando, se esboza, más allá del discurso ideológico y de la retórica nacionalista de la pequeña burguesía republicana, la grave crisis de legitimación en que había desembocado el liberalismo monárquico.

Reposando desde siempre su sistema representativo, especialmente en provincias, en las redes de caciques e influyentes locales (habituales "fabricantes de elecciones" a través de las "chapeladas" ${ }^{3}$ y de los matones por cuenta de los Gobiernos que se alternaban en el control del aparato del Estado), el constitucionalismo monárquico había asociado, a partir de la "paz regeneradora" " ${ }^{4}$, surgida en 1851, caciquismo y turnisrno: o sea, el monopolio de los dos partidos y de las respectivas clientelas en el control del Gobierno y de los puestos del Estado, en régimen de alternancia. Partidos, que, con el tiempo, y a pesar de los cambios producidos en uno de ellos, se tornan política, ideológica e incluso social-

3 Literalmente «sombrerazo" (saludo con el sombrero). En el argot político de la época significaba fraude electoral (equivalente al "puchezaro» en España).

${ }^{4}$ Largo período de calma política y social que sucedió al golpe militar de 1851 , de que vendrá a resultar el predominio del Partido Regenerador en la vida política, y el período designado como Regeneración. 
mente indistintos, como típicas asociaciones esencialmente clientelistas y distribuidoras de sinecuras en sus respectivos turnos de gobierno; partidos, cuyo turnismo consagra la importancia de los medios financieros o de los del comercio colonial e internacional, no obstante el exclusivo acceso a la zona de poder de una oligarquía de grandes intereses ligados a la tierra.

La falta de autenticidad en la representación parlamentaria, debida al sistema caciquil y al bloqueo por parte de la oligarquía turnista del pluralismo político en la gobernación y en la vida política se veía agravada por una legislación electoral censitaria y restrictiva que excluía de la facultad electoral a la abrumadora mayoría de los ciudadanos; en 1890 sólo el 5 por 100 de la población portuguesa tenía derecho al voto. El estrangulamiento de este sistema electoral se agudizó en el último cuarto de siglo, con el desarrollo industrial y el crecimiento de las ciudades. En los principales centros urbanos (entre 1890 y 1911 la población de Lisboa y Oporto aumenta un 44 y un 40 por 100 , respectivamente) el advenimiento de nuevas industrias, el crecimiento de la burocracia estatal, la expansión de los servicios comerciales y de las profesiones liberales origina el desarrollo polarizado de una plebe urbana (el proletariado industrial recién llegado de los campos, el artesanado industrial, los estratos inferiores de los empleados de los servicios políticos, del comercio, etc.), casi completamente desposeída del derecho de participación en el sistema político. Sobre ella, y tendiendo cada vez más a capitalizar y dirigir su descontento político y social, se encuentran los sectores sociales intermedios de la población urbana: la pequeña burguesía de los servicios, de las profesiones liberales, de los negocios pequeños y medios, gentes habitualmente con rentas y cultura que les permiten votar, pero marginados por la oligarquía del área de poder y del acceso a los grandes emprendimientos (y rendimientos) económicos y financieros. Es ésta la base social típica del republicanismo portugués, que en el viraje del siglo, conquistará a las organizaciones obreras socialistas y anarcosindicalistas el liderazgo de la plebe urbana, como fuerza decisiva de maniobra en el ataque a la monarquía.

Y es asimismo ésta la que, buscando conquistar su espacio de participación política, se constituirá en la gran fuerza de presión democratizante del sistema liberal monárquico, presión que evolucionará hacia formas tanto más radicales, cuanto que la monarquia constitucional se muestra totalmente incapaz de cualquier medida seria de reforma que tienda a incorporar al sistema las fuerzas emergentes de la pequeña burguesía urbana. Por el contrario, la crecida de la "ola republicana" se alimenta de la crispación de los últimos gobiernos turnistas (por ejemplo, las medidas represivas de la dictadura de Hintze Ribeiro, 1894-1897) y del estrecha- 
miento defensivo del sistema electoral (leyes electorales crecientemente restrictivas de 1894 y de 1901: refuerzo del carácter censitario del sufragio, exclusión de los analfabetos del derecho de voto, eliminación de la representación de las minorías, disolución del voto urbano mediante la redifinición de los círculos electorales). Medidas que no impiden el proceso de degradación de los partidos turnantes a partir de 1901, y la quiebra final del sistema anunciada por la dictadura de João Franco ${ }^{5}$ en 1907 , antecámara a su vez del regicidio (1908) y de la proclamación de la República el 5 de octubre de 1910.

Pero las contradicciones que enfrentan al bloque social de los marginados del sistema, liderado por los republicanos, a la oligarquía liberal monárquica no son las únicas que se producen en la sociedad portuguesa finisecular. Por eso, si la alternativa del republicanismo (alternativa de la reforma del sistema liberal, mediante su ampliación/democratización a nuevos estratos sociales hasta entonces excluidos del mismo) es la que políticamente se impone en 1910 como solución superadora del impasse institucional en el que desemboca la expresión monárquica del liberalismo portugués, ello no significa que sea la única, ni siquiera la principal, que va a generarse en el proceso de crisis y transformación abierto en 1890$1891^{6}$.

Tal vez es preciso considerar la vertiente económica y social de esa coyuntura para abarcar la dimensión verdaderamente estructural de la crisis que comienza a amenazar al liberalismo portugués, más allá de la mera contestación de la forma monárquica del Estado.

En realidad, las agudas dificultades financieras de los años noventa traen sobre todo aparejada la propia quiebra del modelo económico liberal de la Regeneración. En términos muy generales, éste se asentaba por una parte en un librecambismo agricola, que tenía en Gran Bretaña al socio privilegiado (y generador de una típica relación de dependencia:

5 João Franco, figura destacada de uno de los dos partidos de la monarquía -el Partido Regenerador-, abandonó este partido en 1901, y creó el Partido Regenerador Liberal. Desarrolló un discurso y una práctica en los que algunos autores encuentran aspectos precursores del autoritarismo moderno. Llamado por el Rey en 1906 para dirigir el gobierno, gobernará en régimen de dictadura desde abril de 1907 al 1 de febrero de 1908, fecha del regicidio, que muchos interpretan como una respuesta a las violencias de la dictadura franquista.

${ }^{6}$ Por ser obviamente marginal a los propósitos de este trabajo, no consideramos aquí a la "alternativa obrera" al régimen monárquico-liberal y, después, a la República; alternativa ésta, de alguna manera formulada (por remota que fuese su viabilidad en las condiciones históricas de la sociedad portuguesa de la época) por las corrientes socialistas, anarco-sindicalista, y, a partir de 1921, por la corriente comunista, que fueron sucediéndose en el liderazgo de las organizaciones obreras portuguesas desde 1897. 
Portugal se especializaba en la exportación de productos agrícolas - vinos, frutas, carne, corcho-y, a pesar de algún proteccionismo industrial, era importador de maquinaria, materias primas industriales y productos manufacturados); y por otra, en una práctica sistemática del déficit presupuestario y del endeudamiento interno y externo del Estado, elementos financiadores de los grandes emprendimientos infraestructurales (ferrocarriles y carreteras), lanzados en la segunda mitad del siglo. La crisis internacional de los años noventa herirá de muerte esa política: la pérdida de los mercados agrícolas de exportación, el bloqueo de la financiación externa, el agravamiento del déficit comercial y de la deuda exterior, y, sobre todo, la inexistencia de divisas para contrarrestarlos (la bancarrota del Estado) llevan a los grupos sociales dominantes a considerar la necesidad de imprescindibles revisiones más o menos profundas de sus estrategias económicas y políticas.

Ante el amortiguamiento de la competencia de los capitales y de las mercancias británicas, ante la debilidad del lobby de import-export, se le abre ahora a la débil y bloqueada burguesía industrial la oportunidad histórica de conquistar el mercado interior: sustituyendo imporfaciones, creando nuevas industrias, transformando en su provecho las materias primas nacionales, etc. $Y$, a tal fin, pide al Estado una nueva actitud de intervención política y económica: que contenga las reivindicaciones obreras, desencadenadas con la industrialización del último cuarto del siglo, puesto que carece de poder económico que permita poner en práctica políticas sociales de integración y diálogo; que proteja el mercado nacional y colonial de la competencia exterior; que fomente la conquista de mercados externos; que compense con sus propias finanzas las carencias de capital para inversión industrial; que sea árbitro y agente de compromisos en los contenciosos con los otros sectores de la clase dominante. Aunque, por razones que el propósito de este trabajo nos dispensan de analizar aquí, no parece que pueda hablarse de un take off industrial en Portugal en este periodo, de que esta oportunidad no pudo ser aprovechada para la imposición hegemónica de una estrategia industrializadora, lo cierto es que es ésta una fase de modesto, pero evidente, "despegue industrial' ${ }^{7}$, de aparición de los primeros rudimentos de las industrias básicas (cementos, abonos fosfatados), de la conquista de la pauta proteccionista de 1892, de la reserva del mercado colonial para el sector textil algodonero. La burguesía industrial portuguesa asciende por esa vía al escenario económico y político. Y lo que importa registrar es que desde

\footnotetext{
Cf. Villaverde Cabral, M., Idem.
} 
el primer momento, y en virtud de las debilidades históricas de su proceso de acumulación, lo hace fuertemente apoyada en la protección e intervención del Estado: lo hace postulando una concepción difusamente autoritaria del papel del Estado, que ya tiene poco que ver con los paradigmas tradicionales del Estado liberal.

Es curioso comprobar que la crisis lleva a los sectores de la clase dominante hostiles a la estrategia de la industrialización a reivindicaciones formalmente idénticas en cuanto al papel del Estado: los intereses agrarios del sur piden, y obtienen (leyes de 1889 y 1898) la reserva del mercado interno para el trigo nacional; los grandes viticultores reclaman la exclusiva del mercado colonial; y ambos, "señores del pan y del vino", exigen diversas medidas de intervención estatal, dirigidas a contener los salarios y a fomentar la producción y el beneficio agrícola, sin que se alteren (sino, al contrario, favoreciendo su conservación) las estructuras agrarias tradicionales, amenazadas por el fomento industrial.

En términos generales, la crisis de 1890-1891, al producir una nueva y desigual dinámica de desarrollo y de equilibrio relativo entre los diversos sectores de una clase dominante globalmente débil, dependiente y sin un sector claramente hegemónico, vendrá a implicar para el conjunto de éstos la reformulación, inicialmente vaga y de contenidos concretos variables según las diferentes estrategias, de la concepción del papel y de la naturaleza del Estado: un Estado que interviene en la economía, que acude en auxilio de los sectores en crisis, que protege, que financia, que construye infraestructuras; un Estado dotado de la fuerza, de la autoridad política y del prestigio indispensable para esos fines; es otro modelo de Estado el que las diferentes alternativas autoritarias comienzan a formular, producto de nuevas contradicciones y necesidades originadas por los cambios económicos y sociales de la sociedad portuguesa (y no sólo por éstos) en los albores del siglo xx. La superación, en suma, del liberalismo político y económico, no a través de su regeneración democratizadora - republicana o de otro tipo-, sino mediante la ruptura, postulando un tipo de poder político diferente, de cuño antiliberal y raíz autoritaria. El prolongado y accidentado proceso histórico de decantación, clarificación y conciliación de los diferentes tipos de estrategia implícitos en esta(s) alternativa(s) llevará a la progresiva subordinación de la cuestión de la forma (republicana/monárquica) de Estado en favor de la redefinición de su naturaleza, esto es, conducirá al Estado Novo.

\section{LA QUIEBRA DE LA ALTERNATIVA DEMOCRATIZADORA REPUBLICANA}

Es bien sabidó que la Primera República (1910-1926) fracasó en su tentativa de regeneración democratizadora del liberalismo monárquico. 
Toda su historia es la historia del agitado proceso agónico del liberalismo portugués, ahora en su expresión republicana final.

Si quisiéramos sistematizar, a modo de síntesis sumarísima, las razones principales de la quiebra de la alternativa democratizadora-republicana, nos refeririamos a tres grandes tipos de problemas.

- En primer lugar, el cerco social del republicanismo. Fenómeno pequeño-burgués y esencialmente urbano, la revuelta republicana triunfa en Lisboa y sus alrededores gracias a la correlación de fuerzas allí favorable al bloque social que la protagoniza, y es "proclamada por telégrafo" al resto del país, o sea, es pasivamente consentida, sobre todo en el mundo rural, merced a la situación particular de casi total aislamiento social y político en que se encuentra el régimen monárquico al que antes nos hemos referido. Pero el republicanismo llega al poder en un momento en que ya comienza a ser claro para la mayor parte de las "fuerzas vivas" ${ }^{8}$ que la alternativa al liberalismo monárquico no es el democratismo republicano: ya se tratase del poderoso bloque del conservadurismo agrarista, ya de las fuerzas emergentes del industrialismo, era para ellas cuestión asentada la necesidad de un Estado fuerte, mantenedor del "orden", económica y socialmente intervencionista; un Estado, en suma, no liberal. $Y$, en términos generales, esto les llevará (a pesar de las contradicciones sobre el cometido específico del Estado) a mirar con indisimulada desconfianza y hostilidad a la República, y a alimentar una latente y constante actividad conspiratoria contra la misma. Es cierto sin embargo que la República, y el Partido Democrático ${ }^{9}$ de Alfonso Costa, y luego, de Antonio María da Silva, que representará el gran elemento de continuidad de la gobernación republicana, intentarán siempre, y de manera esforzada, conquistar la confianza de las "fuerzas vivas", o por to menos de sus sectores industriales y de export/import; convencerlos de su competencia y celo para administrar el Estado y sus intereses; ceder a lo esencial de sus exigencias. Pero, por paradójico que parezca, tal actitud tan sólo vino a agravar el aislamiento social del republicanismo: porque, en conjunto, fue incapaz de disuadir a las clases dominantes del proyecto autoritario de liquidación del liberalismo; y, porque en el afán de tranquilizar a los medios burgueses frente a la crecida de la agitación social obrera, los gobiernos republicanos se enzarzaron en una guerra casi permanente contra el movimiento operario, lo que acabaría por alejarles completamente de su aliado del «5 de

\footnotetext{
- Designación empleada en el lenguaje político y periodístico de los primeros treinta años de este siglo para referirse a las fuerzas económicas y sociales del patronato.

9 Designación por la que se conoció al Partido Republicano Portugués, cuando, a partir de 1911. su dirección pasó a ser dominada por el ala radical y jacobina liderada por Alfonso Costa.
} 
Octubre". Si en los momentos cruciales de ofensiva de las derechas, los trabajadores aún acuden a "defender la República" (contra las tentativas de restauración monárquica, en 1919; contra las maniobras y los golpes político-militares de las "fuerzas vivas", en 1924-1925), lo cierto es que acabarán por asistir impasibles, cuando no colaborantes, al golpe de gracia del 28 de mayo de 1926. Aislado de las "fuerzas vivas", divorciado del movimiento obrero, los grandes momentos de crisis económica y política harán incluso desertar del republicanismo a una parte de sus sectores tradicionales de apoyo en las clases medias urbanas: es lo que acontece por los efectos de la Primera Guerra, en 1917, y, posteriormente, por el impacto de las medidas de revalorización del escudo y de equilibrio financiero, en 1924-1925. El republicanismo, más vulnerable que nunca, se vendrá abajo. Primero, en diciembre de 1917, durante el ensayo, algo precoz, de un "autoritarismo moderno", resultante de la revuelta y del consulado sidonista ${ }^{10}$; después, con el «28 de mayo» de $1926{ }^{11}$ que, rico de experiencias anteriores, clausurará de forma duradera la experiencia de noventa y dos años de liberalismo en Portugal.

- En segundo lugar deberá mencionarse la imposibilidad/incapacidad del republicanismo para democratizar el sistema político. Esta situación es fácil de explicar: realidad social minoritaria, y, como hemos visto, relativamente aislada, la pequeña burguesía urbana republicana y su Partido Democrático se oponen a la ampliación y al refuerzo de la transparencia y de la representatividad del sistema político, lo que podría significar para ellos el abandono del área del poder, si no el retorno a cierta marginación política. Así, se caía en esta curiosa situación: a su derecha el Partido Democrático deseaba demostrar su capacidad de gobernar en interés y en nombre de las "fuerzas vivas", pero, para poder hacerlo, tenía que impedir el acceso a la dirección del Estado de los partidos que tendiesen a asumir tal representación, concretamente los partidos de la derecha republicana que eran expresos candidatos a dicha representación. Contra esta concurrencia de la derecha, el jacobinismo alfonsista ${ }^{12}$ lanzará sus milicias privadas («Hormiga Blanca», "Voluntarios para la Defensa de la

${ }^{10}$ El sidonismo fue un régimen político instaurado tras la revuelta militar del 5 de diciembre de 1917, del que fue su figura central el profesor universitario, mayor del Ejército y Presidente de la República, Sidonio Pais. Régimen de ruptura con el constitucionalismo republicano democrático, algunos autores ven en él un ensayo precoz de los nuevos autoritarismos que se impondrán en la Europa de la posguerra (Cf. TELO. António, O sidonismo e o movimento operário português. Lisboa, Ed. Ulmeiro, 1977).

11 Golpe militar que pone término a la Primera República, instalando una dictadura militar, fase de transición hacia la instauración del Estado Novo.

${ }^{12}$ De Alfonso Costa (vid. nota 9). 
República", etc.), que asaltan sedes de periódicos y de partidos, que prenden e intiman, o agitará la Ley de Separación de las Iglesias y el Estado de 1911 en persecuciones político-religiosas, verdadera acción de utierra quemada" para mantener por procedimientos ajenos a la concurrencia política electoral el monopolio del espacio de intervención política, el control del poder, alcanzado entre octubre de 1910 y $1913^{13}$. A su izquierda ocurre otro tanto de lo mismo: frente a la agitación obrera, que crece en razón directa a su desencanto con la República, ésta irá adoptando medidas, a veces de excepcional violencia (disolución de manifestaciones a tiros, deportaciones sin juicio, persecuciones a la prensa, asaltos a sindicatos, abundantes prisiones, etc.), tendentes no sólo a bloquear la participación/concurrencia de los trabajadores en la vida política, sino, sobre todo, a demostrar a las "fuerzas vivas" su capacidad para "mantener el orden", para administrar el Estado contra quienes amenazaban con subvertirlo. Esta recusa en convocar a los trabajadores a la participación política tendrá un elevado coste para la República y para el Partido Democrático: el proletariado organizado radicalizará su lucha, cada vez más al margen y contra el sistema político liberal, colocándose progresivamente en clara ruptura con la República. Naturalmente esta acción represiva a la derecha y a la izquierda se escudaba en el mantenimiento de un sistema político-institucional y electoral que, contrariando las promesas republicanas, no conoce cualquier democratización significativa:

a) El Partido Democrático, principal heredero de la máquina electoral y del caciquismo de los partidos monárquicos, pasa a fabricar (sólo que ahora sin partenaire turnista) los actos electorales: así, ganará sin sorpresas cinco de las seis elecciones parlamentarias a las que concurre durante la Primera República. El monopolio político, la «dictadura del Partido Democrático", tórnase de esta forma indestructible por la vía electoral: sólo cederá por vía de la fuerza, del golpe militar, o, frecuentemente, por razón de propia conveniencia ante el riesgo de que se produzca un golpe. $Y$, normalmente también recuperará el poder, mediante la fuerza, cuando lo pierde a través de ella.

b) La legislación electoral de 1911, 1913 y 1915 no cumple la promesa del sufragio universal: seguirá negando derecho a voto a las mujeres y a los analfabetos, lo que excluye del mismo a la mayoría de los obreros industriales y a la enorme masa de la población campesina. No olvidemos que en 1920 más del 65 por 100 de la población es analfabeta. En las

${ }^{13}$ En 1913 tienen lugar las elecciones parciales que dan la mayoría parlamentaria al Partido Democrático. 
elecciones de 1921, por ejemplo, el número de votantes es el 5,8 por 100 del total de la población, siendo de un 11,2 el porcentaje de la misma con derecho a voto.

c) El impasse del sistema institucional se expresa así en un parlamento de limitada representatividad y que, hasta 1919, no puede constitucionalmente ser disuelto por el Presidente de la República. Pero, incluso después de consagrado el derecho de disolución, en nada contribuye éste para asegurar la alternancia, dado el control del Partido Democrático sobre la máquina electoral. Quedaban así establecidas las condiciones para la inestabilidad política y la amenaza permanente de subversión del sistema: del 5 de octubre de 1910 al 28 de mayo de 1926 la Primera República conocerá cuarenta y cinco gobiernos y veintinueve intentonas revolucionarias.

- En tercero y último lugar se registra la ausencia de una «idea de Estado", de un proyecto político o económico propio del republicanismo, susceptible así de aglutinar un bloque social de apoyo estable y estabilizador. Esa circunstancia, atribuible sin duda a la inestabilidad gubernativa que caracteriza a la Primera República, a la Primera Guerra, etc., tiene tal vez también algo que ver con realidades más profundas: con la propia especificidad política, ideológica, mental de la base social del republicanismo que aglutinaba a una amalgama de estratos sociales urbanos medios, cuya cohesión obedecía sobre todo a objetivos inmediatos de promoción (o de supervivencia) social y política, y que, en cuanto a los objetivos estratégicos, veía su comportamiento sometido a un fenómeno de atracción por parte de los grupos sociales polarizados y de contornos y actuación social y política más afirmados.

El hecho es que el republicanismo llega al poder defendiendo desde siempre la primacía de la "cuestión política", y por tanto con algunas ideas político-institucionales inmediatas - las indispensables para la intervención política de la pequeña burguesía urbana-, pero sin cualesquiera precisiones programáticas en el campo de las reformas económicas y sociales.

Esta actitud, más reveladora de un cierto patrón de comportamiento sociológico que de una consciente pretensión de ocultación política, va a pautar la gobernación republicana: hecha esencialmente de la gestión de una cotidianeidad de crisis y presiones; sin una estrategia de fondo coherente y visible; oscilando a tenor de los vientos coyunturales; pretendiendo sobre todo demostrar su capacidad de gobernar más en relación a algo que por sí misma. Tal es lo que presta a la Primera República esa sensación - que, por otra parte, parece que se corresponde a la realidad histórica del período- de tránsito hacia "otra cosa". 
Los escasos momentos en los que parece definirse un esbozo de política económica coherente -el equilibrio presupuestario de Alfonso Costa en 1913; la política de estabilización financiera de Álvaro de Castro en 1924- no tienen ni continuidad en sí mismos, ni posibilidad de articulación con otros objetivos y medidas. Y lo que más se asemejó a la formulación de una cierta idea del "papel de Portugal en el mundo" y al diseño de un camino para alcanzarla - la política de intervencionismo en la Primera Guerra Mundial - tradújose en una manifestación típica del voluntarismo republicano: el deseo de regenerar a Portugal a golpes de audacia y de diplomacia, sin tocar en los factores estructuralmente condicionantes de la dependencia y del atraso del país. Con sus secuelas de dramáticos efectos económicos, sociales y políticos, la intervención, así concebida y ejecutada, vendría además a agudizar todas las dificultades y contradicciones del régimen, precipitándolo en una crisis, a la que, en último término, el propio régimen acabaría por no sobrevivir.

No obstante, de la Primera República quedaría como legado cultural, cívico y mental importantisimo - acaso no siempre debidamente valorado por cierta historiografía reciente, desmontadora de la tradición historiográfica de exaltación republicana - la obra de secularización del Estado y de la sociedad civil, pieza fundamental de su modernización en términos democráticos. La separación de las Iglesias y del Estado, las leyes de familia, del divorcio, del registro civil, fueron logros culturales y cívicos definitivos de la mentalidad democrática portuguesa que, en sus aspectos esenciales, ni el propio Estado Novo conseguiría remover.

\section{LAS ALTERNATIVAS AUTORITARIAS. LAS «DOS DERECHAS»}

Han sido los trabajos de M. Villaverde Cabral ${ }^{14}$, los que, en contra de cierta tradición historiográfica liberal, llamaron por primera vez la atención en la historiografía portuguesa sobre la necesidad de no confundir las manifestaciones precursoras de lo que se ha llamado el "autoritarismo moderno" - especialmente el "franquismo" y el "sidonismo"- ${ }^{15}$ con el ultramontanismo absolutista y tradicionalista.

La observación y la pista que esta distinción abre me parecen esenciales para comprender mejor la historia portuguesa del siglo $x x$ en ge-

${ }^{14} \mathrm{Cf}$. CABRAL, op. cit. y "A "segunda república" portuguesa numa perspectiva histórica", en Análise Social 1983, vol. XIX (75), 1, págs. 127-142.

${ }^{15} \mathrm{Vid}$. las notas 5 y 10. 
neral, y el fenómeno político, económico y social del Estado Novo en particular, hasta tal punto la dinámica de contradicción-arbitraje entre esas "dos derechas" informa la génesis y la naturaleza del régimen salazarista.

La asimilación en un mismo fenómeno de reacción de esos dos tipos de discurso autoritario posee, sin embargo, alguna razón de ser dimanante del propio proceso histórico de la crisis del liberalismo y del ascenso del autoritarismo en Portugal.

Antes de nada, puesto que ambos constituyen una reacción frente a los mismos problemas, son también respuestas, tentativas, de superación de la crisis del capitalismo de competencia y del Estado liberal iniciada en el tránsito del siglo. Por eso, bien los grupos sociales emergentes de este proceso de transformación, bien aquellos política y socialmente amenazados en su status tradicional; ora los profetas de la modernización, ora los paladines de la conservación desarrollan un discurso formalmente idéntico: critican la inestabilidad política y social que estaría generando el sistema, piden la «moralización" de la vida pública, el "orden", un Estado «fuerte» política y financieramente que pueda, por esta vía, ser un activo protagonista de la vida económica, etc.

Hay una implicación reivindicativa formalmente idéntica que, aunque ocultando profundas diferencias de estrategia entre los grupos sociales dominantes y entre éstos y los sectores medios que se adhieren a tal discurso, parece demostrar la aceptación de una base mínima, política, institucional, económica, de actuación común para la redefinición del Estado y la superación del liberalismo.

Ahora bien, esa convergencia que históricamente se produce, es precisamente lo que impide la clarificación distintiva que el fenómeno merece. Es decir, en las crisis cruciales del liberalismo posteriores a la implantación de la República - crisis de la Gran Guerra, crisis del comienzo de los años veinte- las «dos derechas" se unen y se confunden en un equilibrio inestable para conspirar y derribar el régimen, primero, y después, aunque con manifiesta y creciente conflictividad entre ellas, para intentar gobernar en moldes nuevos (experiencia sidonista de 1917-1918, dictadura militar y Estado Novo desde 1926). A mi juicio, ese comportamiento resulta particularmente característico de la clase dominante portuguesa del primer cuarto del siglo xx, aspecto éste al que ya antes hemos aludido: fuertemente alcanzada por la crisis del sistema, globalmente débil y dependiente, sin sectores claramente capaces de hegemonizar un programa político y económico propio o de generar los correspondientes movimientos políticos. Por todo ello, aparece intensamente dividida en una lucha desesperada en defensa de sus intereses; pero, precisamente por eso mismo, también se ve necesariamente obligada a conjugar fuerzas 
- a través de laboriosos esfuerzos políticos y organizativos - para alcanzar las grandes metas de interés común, y también se siente vitalmente necesitada de la intervención del Estado (en el combate a las reivindicaciones obreras, en el auxilio a los sectores en crisis, en la regulación de la competencia, en el arbitraje de los conflictos internos) para sobrevivir y prosperar. El Estado Novo vendrá a realizar con duradero éxito la síntesis de la experiencia de los éxitos y fracasos de las derechas portuguesas. Como en otro lugar traté de mostrar ${ }^{16}$, representa la estabilización de un equilibrio arbitrado por el salazarismo entre las «dos derechas", entre las fuerzas de la modernización y las de la conservación en la clase dominante, y entre ésta y los sectores intermedios, en un compromiso ideológico y político de raíz autoritaria, antiliberal y antidemocrática, donde coexisten de forma contradictoria los elementos de desarrollo y los de estancamiento en el plano económico.

Si es así, podrá cuestionarse cuál es el interés operativo de distinguir "dos derechas", dos discursos autoritarios, que son sólo acción, que son sólo poder, cuando ambas se confunden y en cierta medida se anulan. No creo que la duda esté justificada: insisto en que la comprensión del proceso histórico de ascensión del autoritarismo moderno y de advenimiento del Estado Novo portugués en sus accidentes, en sus vacilaciones, en su conflictividad, en sus «incoherencias", en suma, en sus especificidades nacionales, pasa en buena medida por la detección y profundización de esta distinción y de su dinámica histórica. Tan sólo registré aquí, de forma rápida, una o dos ideas sumarias sobre esa distinción y esa dinámica histórica.

Prácticamente ausente de la vida política y cultural de los últimos tiempos de la monarquía constitucional, el ultramontanismo absolutista, el pensamiento de la derecha tradicionalista portuguesa, viene a ser redescubierto y remozado, mediante un nuevo tipo de discurso, por el «Integralismo Lusitano" "17, a partir de 1913, o sea, en el contexto de la reacción antirrepublicana.

Con vinculaciones formales tardías -e incluso así, accidentadas y pasajeras - con la corriente monárquica legitimista, con orígenes sociales y culturales casi siempre muy distintos de los de los viejos próceres miguelistas ${ }^{18}$, la joven pléyade intelectual que se agrupa en el «Integralismo

${ }^{16}$ Rosas, Fernando, O Estado Novo nos Anos Trinta. Lisboa, Ed. Estampa, 1987.

${ }_{17}$ Movimiento doctrinario, iniciado por intelectuales monárquicos exiliados en Bélgica, en 1913, en torno a la revista Alma Portuguesa, y políticamente constituido en 1914, en Coimbra, alrededor de la revista Nação Portuguesa. Está fuertemente influenciado por la Action Française y el pensamiento de Charles Maurras.

${ }_{18}$ Partidarios del Rey don Miguel, monarca del régimen absoluto derribado por la revolución liberal de 1834. A sus adeptos, y a los de sus sucesores, se les conocía como legitimistas. 
Lusitano» recreará no obstante el pensamiento del reaccionarismo conservador portugués a través de la matriz maurrasiana. Es innegable la enorme y duradera influencia de muchos de los valores del munus integralista en la política y en la filosofía del conjunto de la derecha portuguesa. La crítica del parlamentarismo y del "demoliberalismo" en general, al que se le contrapone la "representación orgánica" corporativa, superadora de la lucha de clases -esa "invención" del capitalismo y del socialismo; la apología de un "Estado fuerte", dictatorial, donde gobernase -en contraste con el clientelismo y la corrupción de los partidos- la elite de los “mejores»; la exaltación de un nacionalismo retrospectivo, con cuyas tradiciones se reencontraría la nación "rescatada" de un siglo de liberalismo: he aquí un conjunto de ideas que las clases dominantes y la derecha en general integrarán como patrimonio común en el combate al republicanismo liberal.

Pero es evidente que ideas como la defensa a ultranza de la restauración monárquica como objetivo político principal; el origen divino de la legitimidad del monarca absoluto; la apología del ruralismo (restauración del mayorazgo, defensa del latifundio, oposición a la urbanización y al progreso industrial); la denuncia del cientifismo ateo y del avance técnico; la vuelta a la descentralización municipal tutelada por los señores locales, etc., resultan, para los sectores modernizantes de la burguesía, indiferentes, cuando no contrarios a sus aspiraciones. Por eso, tales ideas vendrán a ser factores de indiscutible división de la derecha antiliberal: bastará para comprobarlo, reparar en el resultado que tuvo la precipitada restauración de la monarquía en el norte del país, en enero de 1919, como desembocadura del fracaso de la experiencia sidonista. En realidad, si de las entrañas de la crisis del liberalismo sale esta especie de pretensión de regreso al pasado - tendencialmente vinculado a los grupos sociales dominantes tradicionales más amenazados por las transformaciones agudizadas por la crisis - también sale otro tipo de discurso que pretende abrir paso a los sectores sociales en ascenso, o con pretensiones de ascenso. Un autoritarismo que mira no hacia atrás, hacia la utópica vuelta al Antiguo Regímen, sino a la adaptación del Estado a las nuevas condiciones de desarrollo del capitalismo. El autoritarismo moderno portugués, o si preferimos, la modalidad peculiar del fascismo nacional, acabará por ser, ya lo hemo dicho, la resultante histórica del equilibrio entre las estrategias de estos sectores y las de los grupos más conservadores. Pero lo que torna a este autoritarismo política, institucional, económicamente "moderno", es decir, distinto del tradicional reaccionarismo ruralista, es que se trata de una respuesta, no obstante sus equilibrios y compromisos, a las nuevas contradicciones y aspiraciones resultantes del cre- 
cimiento del capitalismo, y no la prolongación tardía, siglo xx adentro, de las relaciones sociales y políticas del antiguo régimen.

\section{EL «AUTORITARISMO MODERNO»}

Ese carácter «modernizante» - en el sentido que aquí damos a la expresión- está claramente presente en ciertas claves específicas de la teoría y de la práctica de este nuevo tipo de autoritarismo desde sus primeras manifestaciones, más allá de las ideas que heredó y reelaboró del integralismo y que ya antes hemos mencionado. Entre esas claves, podremos señalar:

- La asociación de la apología del Estado autoritario y económicamente intervencionista a la ejecución de un plan de urealizaciones materiales", de fomento económico, generalmente de cariz nacionalista y proteccionista. No es desde luego casualidad que encontremos a casi todas las principales figuras que pensaron Portugal en términos de desarrollo económico desde finales del siglo XIX hasta los años treinta del $x x$, de alguna forma vinculadas a la teorización autoritaria o a sus experiencias: desde Oliveira Martins y Basilio Teles a Quirino de Jesus, Ezequiel Campos o Araújo Correia, siendo sabido cómo la idea de la «dictadura temporal» y regeneradora sedujo a los seareiros ${ }^{19}$ en vísperas del "28 de mayo». En realidad, ya el franquismo hará alarde de un programa de fomento y de obras públicas, públicamente apoyado por los intereses económicos de la época más expresivamente vinculados al desarrollo técnico e industrial (familia Sommer, Alfredo da Silva, y otros "grandes capitalistas»); el «sidonismo», que contará con apoyos idénticos y más amplios entre la "burguesía productiva", se apoya en un partido en cuyo programa se conjugaban el ideario desarrollista neofisiocrático de Oliveira Martins y Ezequiel de Campos ${ }^{20}$; finalmente, el salazarismo insistirá en la crítica al "capital improductivo" y a la "plutocracia», teniendo como imagen emblemática sus planes de "regeneración financiera", de "reconstrucción económica" y de "obras públicas".

- La intuición de la necesidad de un liderazgo carismático, de un nuevo tipo de liderazgo político, adecuado a la coyuntura de crisis, a la ruina de los valores y de las instituciones, al "caos" de la guerra, del

\footnotetext{
${ }^{19}$ Miembros de la revista Seara Nova, publicación de izquierda republicana fundada en 1921 , que durante decenas de años reunió a lo más escogido del pensamiento democrático.

${ }^{20}$ Cf. Egas Moniz, Un ano de política. Lisboa, Ed. Portugal-Brasil Lda. (1919), págs. 60 y ss. y págs. 92 y ss.
} 
hambre, del desempleo, y que explotase demagógicamente, mesiánicamente, la desesperación de las masas; un liderazgo asentado en la relación personal entre las masas y el "jefe", el "salvador», el gran árbitro, profeta de una solución "nacional» y "redentora", por encima de las clases, de los partidos, de la "política" en general. Tal es lo que encontramos ya en el cesarismo real reclamado por Oliveira Martins, en la mass politics que João Franco inaugura como política de los partidos «de orden» ${ }^{21}$, 0 , más claramente, con Sidonio Pais. $Y$, ya bajo la influencia fascista y nacional-socialista, es también la postura que los "camisas azules» ${ }^{22}$ exigen que Salazar asuma en los años treinta, y que el "Jefe» del Estado Novo atemperará con la particular sustancia social, mental e ideológica que será característica de ese régimen en Portugal.

- El populismo moderno, vinculado a la característica anterior, implica el corporativismo, pero es algo más, es decir, es algo más que la negación de la lucha de clases asentada en una concepción orgánica e integral de la nación de raíz corporativa, ampliamente teorizada por toda la derecha portuguesa, con un primer asomo institucional en el Senado sidonista, y consagrada como forma de organización y encuadramiento de las actividades económicas $-y$ no sólo como eso- bajo el Estado Novo. El populismo, como esa apelación directa del ujefe" y del régimen a la masa urbana pasando por encima de sus organizaciones tradicionales, como esa tentativa de movilizarla para imponer o defender "revolucionariamente" la nueva situación contra el capitalismo y el socialismo, a modo de tercera vía simultáneamente nacional y social o sindical, está presente embrionariamente en esa forma sin precedentes, que João Franco inaugura, de que "un estadista portugués se dirija tan de cerca a la multitud" ${ }^{23}$. Resurge en el frustrado diálogo que el sidonismo, en sus comienzos, trata de establecer con las organizaciones obreras ${ }^{24}, y$, después, en el discurso "obrero" de los pequeños grupos y movimientos fascistizantes que, salidos del integralismo, surgen en Portugal desde el inicio de los veinte, de los que el más típicamente representativo vendrá a ser el Movimiento Nacional Sindicalista de Rolão Preto. Pero ese vector populista no constituirá nunca una característica relevante del Estado Novo portugués, com-

21 Cf. Villaverde Cabral, Idem.

22 Uniforme de los miembros del Movimiento Nacionalsindicalista, organización radical de tipo fascista fundada en 1932, y que será ilegalizada por el «Estado Novo» en 1934. Su jefe era el ex-integralista Rolão Preto

${ }^{23}$ Rocha Martins, Portugal dos nosos dias - vermelhos, brancos e azuis. Lisboa, Vida Mundial, 1948, vol. I, pág. 31.

${ }^{24}$ Cf. VILlaverde CABraL, "A grande guerra e o sidonismo (esboço interpretativo)", en Analise Social 1979, vol. XV (58), 2. ${ }^{\circ}$, págs. 373 a 392. 
binación social y política específica de las clases dominantes y medias, que siempre mirarán con total desconfianza - y hasta con sensación de peligro- los movimientos de masas, por definición potencialmente incontrolables, incluso cuando se trata de apoyar al régimen.

- La subalternización de la "cuestión del régimen", de la forma de Estado (republicana o monárquica) en beneficio de la definición e imposición de un nuevo tipo de Estado: antiliberal, antiparlamentario, antisocialista, corporativo y autoritario. Este es uno de los puntos de política y de táctica que más separará a la "nueva derecha" de los viejos monárquicos de la primera generación integralista. Habiendo asimilado la lección de la derrota de su primera experiencia histórica de reorganización antiliberal del Estado sobre nuevos moldes -el sidonismo, echado a perder entre otras razones por la división creada en su bloque social de apoyo por el restauracionismo monárquico- las clases dominantes tratan de unirse en los años veinte en torno de lo que es esencial para el asalto decisivo al poder. El compromiso político-institucional que estructura la fronda social del Estado Novo pasará por la aceptación de la forma republicana de Estado, incluso al precio de la ruptura con las grandes figuras fundadoras del integralismo.

- La concentración política del aparato represivo y la creación de organizaciones milicianas. En este terreno todos los ensayos autoritarios en Portugal, desde la experiencia franquista, buscarán crear o reforzar y centralizar, de acuerdo con las necesidades y principios políticos del régimen, un cuerpo policial secreto, especializado en la información y represión política violenta, rápidamente transformado en pieza principal del aparato represivo e instrumento decisivo para la supervivencia de la situación implantada. Si con las persecuciones del Juicio de Instrucción Criminal, en la dictadura de João Franco, aún estamos en la infancia de este "arte», ya la represión masiva y las violencias de la policía secreta sidonista de Sollari Alegro ${ }^{25}$ constituirán una significativa anticipación de la Policía de Vigilancia y Defensa del Estado (PVDE), fruto final de la reorganización y centralización de las policías operadas por Salazar en 1933. Para lo cual - dicho sea de paso- fue de decisiva importancia la contribución de las policías republicanas, desarrolladas y perfeccionadas en los años veinte en la represión del movimiento obrero.

Las organizaciones milicianas por su parte tienen un papel más subalterno en el proceso de ascenso y consolidación del autoritarismo mo-

${ }^{25}$ Político monárquico sidonista, que reorganizará y dirigirá la policía política de la «República Nova" en el norte del país, tristemente célebre por las violencias cometidas contra los presos políticos. 
derno en Portugal. No asentándose éste, en el caso portugués, en el "asalto" al poder conducido por partidos o movimientos de masas paramilitares (la aproximación en ese sentido del Movimiento Nacional Sindicalista es de consecuencias prácticas casi irrelevantes), las organizaciones milicianas - contempladas con franca desconfianza por el Ejército, tutor de la «Revolución Nacional»- surgirán entre nosotros tardiamen$\mathrm{te}^{26}$, sobre todo por influencia de la guerra civil de España, vinculadas a la defensa y consolidación del régimen frente a la "amenaza roja" española, y siempre estrechamente controladas y bajo la dependencia orgánica del Estado.

- La necesidad de un "partido único": fue éste históricamente en Portugal un instrumento orgánico fundamental para hacer viable el triunfo del autoritarismo moderno. No en la acepción común de un movimiento vanguardista y dirigente de la conquista del poder -otros son los caminos de la toma del poder por las derechas portuguesas-, sino en el sentido más amplio de lo imprescindible de una previa definición institucionalizada de la plataforma común unificadora de las estrategias políticas y económicas de una clase dominante tan característicamente débil y dividida como vimos que era la portuguesa del primer cuarto del siglo xx. Ya Sidonio Pais intuirá la importancia vital de la cuestión para la supervivencia de su "República Nova» al lanzar el frustrado proyecto de un "partido único» del sidonismo en 1918, el «Partido Nacional Republicano», y, ante el fracaso del proyecto, al sustituir ese partido por su figura personal como último factor de congregación. Pero son los políticos del Centro Católico ${ }^{27}$ de Salazar los que más amplia y laboriosamente trabajan en este proyecto de compromiso de "toda la burguesía" desde los años veinte. Conseguida una operatividad mínima para el desencadenamiento del golpe del «28 de mayo", a través de una red frágil y compleja de organizaciones patronales y políticas unificadoras (enseguida disuelta en la aguda disputa que sucede a la implantación de la dictadura militar), será finalmente la Unión Nacional, en 1930, la que fije las bases del acuerdo político y social común que torne viable el Estado Novo. Obra de Salazar, su propia figura, su papel individual será un factor personal decisivo en la definición, sal-

${ }^{26}$ Tras la corta vida activa de una "Associação Escolar Vanguarda», surgida en 1934 como organización de la juventud, el Estado Novo crea en 1936, bajo su estrecha tutela, la "Mocidade Portuguesa" y la «Legiāo Portuguesa", organizaciones paramilitares que usarán camisas de color verde.

27 Partido católico vinculado a la Iglesia, fundado en 1894 y reorganizado en 1914. Dentro de él destacará como figura principal en los años veinte Oliveira Salazar. El Centro Católico desarrolló una acción decisiva en pos de la unificación de las fuerzas conservadoras, defendiendo el carácter secundario de la cuestión de régimen. 
vaguarda y arbitraje de la plataforma así definida. Partido subalterno y dependiente del Estado, sin fuerza anímica propia, sin autonomía, la Unión Nacional, y otras instituciones como la Asamblea Nacional, tienen sin embargo la importancia, no siempre perceptibne de forma inmediata, de funcionar como órganos de un frente político, puntos de encuentro, areópagos de diálogo, composición y arbitraje de intereses entre los diversos sectores de los grupos sociales dominantes, elementos institucionales sin los cuales sería cuestionable la estabilidad y la propia viabilidad del nuevo régimen.

De lo que hasta aquí hemos expuesto tal vez puedan detectarse dos particularidades especialmente destacables del proceso de crisis del liberalismo portugués desde la última década del siglo XIX: por un lado, su carácter prolongado, casi de ir arrastrándose, dentro de cuyo contexto coexisten el fracaso de la reforma democratizante-republicana del sistema, la inviabilidad de la alternativa revolucionaria-obrera, y la relativa dificultad, jalonada en las diversas tentativas a lo largo de más de un cuarto de siglo, de entendimiento de las clases dominantes para la imposición de su alternativa autoritaria y antiliberal; por otro lado, este último aspecto, que se prende al contexto económico, social y mental específico de la sociedad portuguesa de la época, acabó por condicionar el particular perfil político, económico e ideológico del Estado Novo portugués. A pesar de que en él encontramos los trazos esenciales del «autoritarismo moderno" de entreguerras, su carácter equilibrador, compromisario y arbitral entre factores de cambio y de estancamiento determinará un régimen del que estarán ausentes, o sólo moderadamente presentes, algunos de los aspectos político-ideológicos típicos de otras experiencias fascistas coetáneas: el revolucionarismo populista, la exacerbación del fhürerprinzip, el culto de la fuerza y de la violencia, el racismo, las "tropas de asalto" milicianas, o incluso buena parte de la grandiosidad iconográfica de este tipo de regímenes.

El largo y no siempre fácil parto del "autoritarismo moderno" portugués generaría ese peculiar Estado Novo, donde las modernas industrias del cemento, de los abonos o de las refinerías, crecerian y se concentrarían en los años treinta a la sombra de la cruz y de la espada, envueltas en el culto de la gesta pasada de nautas, santos y caballeros y en la oratoria exaltadora de las excelencias de la vida rural. 